\title{
MulawarmanLawReview
}

\section{Justice Constitutionality of Specialized Court in Coping with the Dispute on Direct Local Leader Election Result}

\author{
Ebin Marwi \\ Badan Pengawas Pemilihan Umum (BAWASLU) Provinsi Kalimantan Timur, Indonesia. \\ E-mail: ebinmarwi@yahoo.co.id
}

\begin{abstract}
In accordance with the petition of Constitutional Court Number 97/PUU-XI/2013, Constitutional Court is no longer authorized to resolves disputes on direct Local Leader Election result, because provisions of Article 236C of Law Number 12 Year 2018 Republic of Indonesia against the constitution of 1945 Article 157 paragraph (1) Law Number 8 Year 2018 determines that the dispute settlement on direct Local Leader Election results become the authority of specialized judiciary. But before a specialized judiciary is formed, then the Constitutional Court is authorized to resolve disputes on direct Local Leader Election results. The authority of the Constitutional Court is the constituional authority to fulfill temporary vacuum of norm (rechtvakum). Therefore Legislators should immediately establish a specialized judiciary which has the authority to resolve the disputes on direct Local Leader Election result.
\end{abstract}

Keywords: Authority; Constituional Court; Election; Election Law.

Citation: Marwi, Ebin. "Justice Constitutionality of Specialized Court in Coping with the Dispute on Direct Local Leader Election Result.” Mulawarman Law Review 3, no. 2 (2018): $89-96$

\section{INTRODUCTION}

Authority decides dispute on Local Leader Election has changed, from the Supreme Court which authorized, then it switches to Constitutional Court, then Specialized Court is formed. Resolving process of dispute on Local Leader Election is divided into two forms: (1) dispute related with Local Leader Election holding which is resolved by The Local Leader Election Supervisory Agency and Administrative Court; and (2) Dispute of Local Leader Election result which is resolved by Specialized Court. Until the formed of that Specialized Court, dispute is still resolved by the Constitutional Court (hereinafter, MK).

Ideally, the rights to vote as well as be voted must be restricted in a way that the process of fair election and generate a government capable of exercising the mandate 
of the people ${ }^{1}$. However, there are several related issue with that Specialized Court. First, Constitutional does not give provisions detail about structure and the authority of Specialized Court. Second, there is differentiation with settlement agency of Local Leader Election dispute, whereas dispute on Local Leader Election needs strong agency and judges who has special competence on Election sector. Third, there is detail design related with that court, whethere it is ad hoc or permanent: whether procedural law on that dispute resolving has final and legal binding like Constitutional Court authority or there are the availability of appeal and cassation appeal laws efforts.

Above all, the main issues in this research is concerning the constitutionality of Specialized Court to resolve dispute on direct Local Leader Election and analyzing the ideal concept of special court to resolve dispute on direct election in Indonesia.

\section{Method}

Normative laws research method or this normative law doctrinal research is as library research or document study because this research is done or aimed just to written regulations or other law legal materials. ${ }^{2}$ The conclusion this research which is done by researching literature materials or secondary data which consist of primary legal material, secondary legal material and tertiary legal material.

Normative laws research method or this normative law doctrinal research is as library research or document study because this research is done or aimed just to written regulations or other law legal materials.

Legal material which is obtained will be analyzed by using interpretation and law construction. By doing law interpretation, it will be done legal interpretation through legal invention (rechtsvinding). Then, law construction is done through legal argumentation a contrario ${ }^{3}$ will answer legal issue. As the result, with that legal invention method will be produced legal argumentation which can answer legal issue through logical and systematic of legal reasoning.

Legal material which is obtained will be analyzed by using interpretation and law construction. By doing law interpretation, it will be done legal interpretation through legal invention (rechtsvinding). Then, law construction is done through legal argumentation.

\footnotetext{
${ }^{1}$ Khairul Fahmi, Zainal Arifin Mochtar, Saldi Isra, Zulkifli Aspan. "The Restriction of Suffrage in the Perspective of Fair Election in Indonesia." Hasanuddin Law Review, 4 No. 1 (2018): 41.

2 Soerjono Soekanto and Sri Mamudji, "Penelitian Hukum Normatif", Cetakan ke-8, PT. Raja Grafindo Persada, Jakarta, 2004, hlm.14

3 Peter Mahmud Marzuki, Penelitian Hukum, Kencana Prenada Media Group, Jakarta, 2011, hlm.47
} 


\section{Discussion}

Justice Constitutionality of Specialized Court in Coping with The Dispute on Direct Local Leader Election Result in Indonesia

In Local Leader Election holding based on principles, public, free, secret, honest, and fair. But, in its holding has potention to evoke violation and dispute. Dispute on direct Local Leader Election has quantitative characteristic because of mistake on vote counting, or qualitative dispute related with Local Leader Election process and its effect.

Dispute on that direct Local Leader Election result must be resolved according the law (due process of law). As law state, dispute of direct Local Leader Election result must be resolved through agency and according to procedures which is determined by law. Dispute must be resolved by upholding democray values, resolving the dispute with peace and instituionalize. ${ }^{4}$

In Terminology, there is term changing from direct Local Leader Election becomes General Local Leader Election through Act Number 22 Year 2007 about Public Local Leader Election Holding. That amandemen start since Constitutional Court Petition Number 072-73/PUU-II/2004, date 22 March 2005. In that petition, Constitution Court gives space to form constitution to extend General Election meaning in provisions of Article 22E of Constitution of Republic of Indonesia 1945. But, in fact Local Leader Election meaning becomes General Local Leader Election is considered against with Article 22E of Constitution of Republic of Indonesia Year 1945. That amandement is judged against with provisions in Article 37 of Constitutions of Republic of Indonesia Year 1945, because it is not through formal procedure which is determined.

That terminology changing brings basic change on authorized agency to resolve Direct local leader election dispute result, they are Supreme Court to Constitutional Court. That changing is based on Constitutional Court authority to resolve dispute of general election as it is determined in Article 24C Section (1) of Constitution of Republic of Indonesia Year 1945 which determines that Constitutional Court authorize to judge on the first and the last levels of their final petition and it cuts dispute about general election, based on that provisions, then based on Article 236C Act Number 12 about The Second Amandement of Act Number 32 Year 2004 about Local Government, is determined that Supreme Constitution to resolve that Direct local leader election result is switched to Constitutional Court authority.

4 Henry B. Mayo dalam Taufiqurrohman Syahuri, Putusan Mahkamah Konstitusi Tentang Perselisihan Hasil Penghitungan Suara Pemilihan Umum Berdasarkan Undang-Undang No. 24 Tahun 2003, Jurnal Konstitusi, PKK-FH Universitas Bengkulu, Bengkulu, Vol. II No.1 Juni 2009, hlm. 10 
Authority switch in dispute resolving on Local Election causes pros-cons among administrative law experts. It reminds in provisions of Article 24C of Constitution of Republic of Indonesia Year 1945 and Article 10 of Act Number 24 Year 2003 about Constitutional Court just give authority to Supreme Court to resolve dispute on General Election Result Gramatically and original intent are general election which is determined in Article 22E Section (2) of Constitution of Republic of Indonesia Year 1945. Therefore, many experts stated that authority switch in dispute resolving on Direct local leader election result to Constitutional Court is unconstitutional. In the other side, a half of administrative law experts state that authority switch is

Despite, it causes controversy academically. Constitution Court still do authority which is given by Article Number 48 of Act Number 12 Year 2008. Thus, in Act Number 48 Year 2009 about Judicial Affair Authority also give basic law for Constitutional authority to resolve dispute on Direct local leader election result.

Pros-Cons is end in 2013 when Constitutional Court stated that Constitutional Cour did not have authorize to judge Direct local leader election dispute. It is put in Constitution Court Petition Number 97/PUU-XI/2013. Ratio decidendi dictum in Constitutional Petition Number 97/PUU-XI/2013 to determine the giving of authority to resolve dispute on Direct local leader election result to Constitutional Court which is given through provisions in Article 263C of Act Number 12 Year 2008 and Article 29 Section (1) item e of Act Number 48 Year 2009 is unconstitutional and must be revoted, because it against with Article $24 \mathrm{C}$ section (1) and Article 22E section (2) of Constitution of Republic of Indonesia Year 1945 and it does not have law enforceable.

As the result, Constitutional court does not have authority to judge, examine, and cut the dispute on Direct local leader election. The main reason of that petition is because Direct local leader election cannot be equalized with General Election regime which is managed in Article 22E section (2) of Constitution of Republic of Indonesia Year 1945, with the result to resolve dispute on Direct local leader election to Constitutional Court is unconstituional and must be revoted.

With that basic petition, Constitutional Court gives freedom to form Law to determine which judiciary that is authorized to resolve dispute on Local Election result. But, that dictum aims to fill (vacuum of norm), with the result the Legislator is demanded to resolve dispute on Direct local leader election result. That Constitutional authority is just temporary and is win-win solution, although it still causes administrative controversy.

After Constitutional Court petition Number 97/PUU-XI/2013 above, wetgever/Legislator establish that: "In case of dispute happened, vote acquisition determination, election participants can submit cancellation request of vote acquisition calculation result by Province General Elections Commission and 
Regional/City General Elections Commission to High Court which is appointed by Supreme Court". It means from that provisions, then who has authority to resolve Direct local leader election result is high court which is appointed by Supreme Court.

Thus the provisions in that Article 157 section (1) of Act Year 2015 does not valid for long, because Legislator change it with Act Number 10 Year 2016. That Law changing also bring changing on authorized judiciary to resolve dispute on Direct local leader election. Related with that issue, that Law Article 175 managed that:

1. Dispute issue of election result are checked and judged by Specialized Court.

2. Specialized Court as it is mentioned in section (1) is formed before national simultaneous election.

3. The case of vote acquisition result determination is checked and judged by Constitutional Court until Specialized Court is formed.

Based on that provisions, switch is happened to authorized judiciary to resolve dispute on Direct local leader election result, where dispute on Direct local leader election result is resolved by Specialized Court. Thus, Specialized Court which is meant, Article 157 of Act Number 10 Year 2016 does not determine with limit. This article just determine that Specialized Court will be formed before national simultaneous Local Election.

That provision is inaccurate formulation considering Constitutional Court decides themselves does not authority anymore to resolve dispute on Direct Local Leader Election result. It is caused because that provisions is provision which is doubt, it is considering provisions in Article 201 section (7) of Act Number 10 Year 2016 to determine that national Local Leader Election will be held in 2017. It means, that provisions substansively against with Constitutional Court which give authority to Legislator to point authorized judiciary to resolve dispute on Direct Local Leader Election result.

The cause of authorized agency obscurity, then it fills vacuum or norm (recht vacum), Article 157 section (3) of Act Number 10 Year 2016 determine that Constitutional Court is given authority to resolve dispute of Direct Local Leader Election until the formed of Specialized Court which has competence to resolve dispute on Direct Local Leader Election. That provision is determined in dictum number 2 of Constitutional Court petition Number 97/PUU-XI/2013 which determine that: "Constitution is still authorized to judge General Local Leader Election result as long as there is not constitution which organize that issue".

Legal norm which is on dictum number 2 of Constitutional Court petition Number 97/PUU-XI/2013 and article 157 section (3) of Act Number 10 Year 2016 there are several very basic weakness. It because it against with dictum number 1 Constitutional 
Court petition Number 97/PUU-XI/2013 determine that norme on Article 236C of Act Number 12 Year 2008 and norme on Article 29 section (1) item e of Act Number 48 Year 2009 about Judicial Authority that against with Constitution of Republic of Indonesia 1945 also it does not have law enforceable, with the result that Constitutional Court does not have authority anymore to resolve dispute on Direct Local Leader Election result.

Therefore, it becomes illogical if it comes through Article 175 section (3) of Act Number 10 Year 2016 gives authority to Constitutional Court to resolve dispute on Direct Local Leader Election. Despite that issue is possibled by dictum number 2 of Constitutional Court petition Number 97/PUU-XI/2013, but Legislator should understand that dictum is just temporary. Because in that law must be determined the authorized judiciary. If they wait until the formed of Specialized court, then Constitutional Court authority which is given in Article 157 section (3) of Act Number 10 Year 2016 is not temporary, because it needs time until year 2027. It does not give law certainty in administrative practice, especially in local governance holding in Indonesia.

\section{Election Supervisory Agency as Specialized Court}

One of other agency which is mandated specially by Law is Specialized Court. This agency indirectly is mentioned juridically will handle dispute on Direct Local Leader Election, but it can be formed as juridical solution among society in Direct Local Leader Election. This agency becomes the best solution to "reduce" Constitutional Court burnden to be more focus to handle constitutional issue and their limit authority. ${ }^{5}$

Election Supervisory Agency shold be considered as Specialized Court, because legal effort in court process which is layered and takes time with the result it is contraproductive with Local Leader Election stages. Futhermore if Local Leader Election is held simultaneously, recent common justice mechanism usage that the fair Local Leader Election will be hard to be realized.

Idea to make Election Supervisory Agency as agency which is authorized to judge dispute on Local Leader Election result is not impossible issue. It because there is change ion Election Supervisory Agency that the first it just becomes supervisor of General Election now has quasi judicial authority in General Election administration dispute and General Election criminal law. ${ }^{6}$

5 R. Nazriyah. "Penyelesaian Sengketa Pilkada Setelah Putusan Mahkamah Konstitusi Nomor 97/PUU-XI/2013", Jurnal Konstitusi, Vol 12. Nomor 3, September 2015. hlm. 457.

6 Muhammad, 2013, Menilik Kesiapan Bawaslu dalam Menangani Pelanggaran dan Sengketa Pemilu 2014, Jurnal Pemilu dan Demokrasi, jurnal \# 6, Perludem, 2-13, Jakarta, hlm. 19. 
In Law of Local Leader Election, Election Supervisory Agency accept the objection from Local Leader Election participant who feel they are aggrieved with Province or Regional/City General Election Commission. Local Leader Election participant who feel they are aggrieved can submit their objection after General Election Commission determine the decision. In this case, Election Supervisory Agency is affirmed as implementer of administrative appeal where Local Leader Election participant is required to submit their objection to Election Supervisory Agency in General Election administrative affair. After Election Supervisory Agency gives the decision, but Local Leader Election candidate or participant does not feel satisfy can be submitted accusation on administrative dispute on election to Administrative High Court after all administrative effort in Election Supervisory Agency is finished.

Author sees there is tendncy to make Election Supervisory Agency as an agency which can resolve the case and becomes quasi judicial agency. Furthermore the addition for this authority to be possible becomes increased to be given the additional authority for Election Supervisory Agency to transform become General Election court.

\section{CONCLUSION}

1.1 Based on constitution, dispute resolving agency of Direct Local Leader Election result experienced changing from the original authority by Supreme Court, it becomes Constitutional Court authority, then that authority becomes authority for Specialized Court. Before Specialized Court is formed, Constitutional Court still has authority to resolve Direct Local Leader Election. That Constitutional Court authority is constitutional authority which is temporary. But in fact this authority against with that Constitutional Court petition substance itself. Because, Legislator must form Specialized Court immediately which has authority to resolve dispute on Direct Local Leader Election.

1.2 Special court for Local Leader Election is very urgent to be formed. He existence of Election Supervisory Agency was determined from part of semi-justice is relevant renewal as one of legal policy to welcome simultaneous Local Leader Election in 2027. But, special court design for Local Leader Election in Indonesia must be adjusted with Nation condition. Court design which is fit is design with ad hoc characteristic, also has authority to judge all disputes which are appeared in Local Leader Election process, started from administration dispute, Local Leader Election criminal act to 


\section{REFERENCES}

Soerjono Soekanto dan Sri Mamudji, Penelitian Hukum Normatif, Cetakan ke-8, PT. Raja Grafindo Persada, Jakarta, 2004.

Peter Mahmud Marzuki, Penelitian Hukum, Kencana Prenada Media Group, Jakarta, 2011.

Henry B. Mayo dalam Taufiqurrohman Syahuri, Putusan Mahkamah Konstitusi Tentang Perselisihan Hasil Penghitungan Suara Pemilihan Umum Berdasarkan Undang-Undang No. 24 Tahun 2003, Jurnal Konstitusi, PKK-FH Universitas Bengkulu, Bengkulu, Vol. II No.1 Juni 2009.

R. Nazriyah. "Penyelesaian Sengketa Pilkada Setelah Putusan Mahkamah Konstitusi Nomor 97/PUU-XI/2013", Jurnal Konstitusi, Vol 12. Nomor 3, September 2015.

Muhammad, 2013, Menilik Kesiapan Bawaslu dalam Menangani Pelanggaran dan Sengketa Pemilu 2014, Jurnal Pemilu dan Demokrasi, jurnal \# 6, Perludem, 213, Jakarta.

Fahmi, K., Mochtar, Z., Isra, S., \& Aspan, Z. (2018). The Restriction of Suffrage in the Perspective of Fair Election in Indonesia. Hasanuddin Law Review, 4(1), 41-53 